\title{
Spray temperature and spray volume influence on the efficacy of carfentrazone-ethyl and saflufenacil to control morning-glory
}

\section{Mauricio Crestani Agostineto, Humberto Henrique Ansolin, and Leonardo Bianco de Carvalho*}

\author{
Santa Catarina State University, Centre of Agroveterinary Sciences, Lages, SC, Brazil
}

\begin{abstract}
The objective of this research was to relate the response of Ipomoea hederifolia and Ipomoea quamoclit with the variation of spray temperature and spray volume of carfentrazone-ethyl and saflufenacil. Two pot-experiments were carried out to relate the spray temperatures $(10,20$, and $30^{\circ} \mathrm{C}$ ) and spray volumes $\left(150,200\right.$, and $\left.250 \mathrm{~L} \mathrm{ha}^{-1}\right)$ with the plant dry mass accumulation after application of $2 \mathrm{~mL} \mathrm{ha}^{-1}$ and $0.5 \mathrm{~g} \mathrm{ha}^{-1}$ of the labeled herbicide with carfentrazone-ethyl (Aurora ${ }^{\circledR}$ ) and saflufenacil $\left(\mathrm{Heat}\left(\mathrm{B}_{)}\right)\right.$. Fourteen days after application, shoot dry mass was determined. Data were expressed in relation to the herbicide-free check and submitted to linear regression analysis. Increasing $10 \mathrm{~L} \mathrm{ha}^{-1}$ in spray volume reduces $1.34 \%$ of the dry mass of both species, by using carfentrazone-ethyl, and $2.32 \%$ and $1.93 \%$ of the dry mass of $I$. hederifolia and $I$. quamoclit, respectively, by using saflufencil. In addition, increasing $1^{\circ} \mathrm{C}$ in spray temperature reduces $0.22 \%$ and $0.35 \%$ of the dry mass of $I$. hederifolia and $I$. quamoclit, respectively, by using carfentrazoneethyl, and $0.56 \%$ and $0.30 \%$ of those species, respectively, by using saflufenacil. The efficacy of carfentrazone-ethyl and saflufenacil to control $I$. hederifolia and $I$. quamoclit is dependent on both spray temperature and spray volume. The use of spray temperature next to $30{ }^{\circ} \mathrm{C}$ and spray volume next to $250 \mathrm{~L} \mathrm{ha}^{-1}$ can provide a better control of those species.
\end{abstract}

Keywords: PPO inhibitors, herbicides, spray characteristics. 


\section{INTRODUCTION}

Morning-glory species (Ipomoea spp.) commonly infest agricultural areas in Brazil (Kuva et al. 2007, Ferreira et al. 2011, Giancotti et al. 2014), providing indirectly interference on the crop productivity by machinery blocking during mechanical harvesting, in addition to the direct interference on crops by competition for environmental resources (Carvalho et al. 2009, Carvalho et al. 2014). Among several morning-glory species, Ipomoea hederifolia and Ipomoea quamoclit have been two of the major weeds occurring in sugar cane, soybean, maize, and other crops (Agostineto et al., 2015). To control morning-glory species, herbicides inhibiting the enzyme protoporphyrinogen oxidase (PPO) such as carfentrazone-ethyl and saflufenacil, are been recommended (MAPA 2014a,b).

The application of pesticides under inadequate spray conditions affects the efficacy of the agrochemicals on controlling pests (Nicolai and Christoffoleti 2014). In this way, spray volume and spray temperature can play an important role on the efficacy of herbicides to control weeds, as observed by Downer et al. (1998), Galon et al. (2007), Cunha et al. (2010), Campos et al. (2011), among others. Thus, the objective of this research was to relate the response of I. hederifolia and I. quamoclit with the variation of spray temperature and spray volume of carfentrazone-ethyl and saflufenacil.

\section{MATERIAL AND METHODS}

Two pot-experiments were carried out to study the role of spray temperature and spray volume on the efficacy of carfentrazone-ethyl and saflufenacil to control morning-glory. In both experiments, young plants of I. hederifolia and $I$. quamoclit grew during October and December 2014 in 5-L pots filled with a mixture of soil and organic substrate in a 4:1 proportion (v:v). Before sowing, $2 \mathrm{~g}$ of NPK (5-20-10) and $3 \mathrm{~g}$ of urea were applied. After sowing, plants were daily irrigated with $150 \mathrm{~mL}$ of water. Two plants grew in each pot and the pots were maintained under environmental conditions during the experiment (that are repeated twice for each experiment).

In the experiment on spray temperature, treatments consisted of a $2 \times 3$ factorial scheme, where we tested two morning-glory species (I. hederifolia and I. quamoclit) and three spray volumes (150, 200, and $250 \mathrm{~L} \mathrm{ha}^{-1}$ ), maintaining a herbicide-free check, arranged in a completely randomized design with four replicates.

In the experiment on spray volume, treatments consisted of a $2 \times 3$ factorial scheme, where we tested two morning-glory species ( $I$. hederifolia and
I. quamoclit) and three spray temperatures $(10,20$, and $30{ }^{\circ} \mathrm{C}$ ), maintaining a herbicide-free check, arranged in a completely randomized design with four replicates.

For both experiments, $2 \mathrm{~mL} \mathrm{ha}^{-1}$ and $0.5 \mathrm{~g} \mathrm{ha}^{-1}$ of the labeled herbicide, respectively for carfentrazoneethyl (Aurora $\AA, 400 \mathrm{~g}$ ai $\mathrm{L}^{-1}$, FMC, Brazil) and saflufenacil (Heat $\circledast$, $700 \mathrm{~g}$ ai $\mathrm{kg}^{-1}$, Basf, Brazil), were sprayed using a $\mathrm{CO}_{2}$-pressurized sprayer equipped with flat plan nozzles (TeeJet, 80.02, USA). The herbicide doses were determined in previous experiments (Agostineto et al. 2015), choosing sub-lethal doses causing differences on the plantresponse.

Fourteen days after herbicide application, plants were cut off close to soil and dried for $96 \mathrm{~h}$ in a forced air oven at $60{ }^{\circ} \mathrm{C}$. After drying, plant material was weighted in an analytical balance $(0.001 \mathrm{~g})$ for dry mass determination.

Data were submitted to linear regression analysis performed by using SigmaPlot ${ }^{\circledR}$ (Systat, version 10.0, USA).

\section{RESULTS}

Spray volume. The ANOVA was not significant $(P>0.05)$ to plant species, indicating that both I. hederifolia and I. quamoclit responded similarly to carfentrazone-ethyl spraying when spray volume was increased. Therefore, just one equation provided the relation between the increasing of spray volume and the effect on the decreasing of dry mass of both species (Figure 1). According to the equation, increasing $10 \mathrm{~L} \mathrm{ha}^{-1}$ in spray volume reduces $1.34 \%$ of the dry mass, indicating that high spray volume provide higher efficacy of carfentrazone-ethyl to control both species.

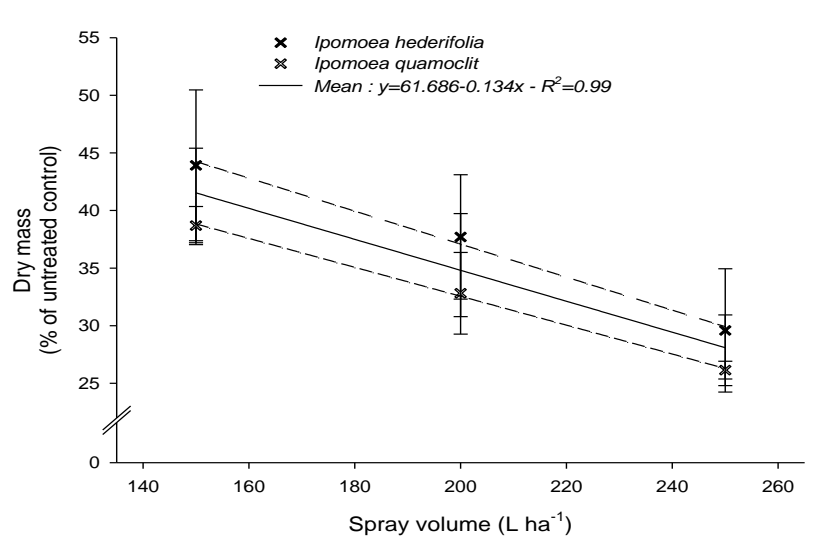

Figure 1. Relation between the percentage of dry mass of Ipomoea hederifolia and Ipomoea quamoclit, compared to a herbicide-free check, and the spray volume applied with carfentrazone-ethyl (Aurora $\AA$, $400 \mathrm{~g}$ ai L-1, FMC, Brazil). Vertical lines indicate the standard error of the mean of four replicates. 
The ANOVA was significant $(P<0.05)$ to plant species, indicating that $I$. hederifolia and $I$. quamoclit responded differently to saflufenacil spraying when spray volume increased, so that two equations were required to provide the relation between the increasing of spray volume and the effect on the decreasing of dry mass of both species (Figure 2). According to the equation, increasing $10 \mathrm{~L} \mathrm{ha}^{-1}$ in spray volume reduces $2.32 \%$ and $1.93 \%$ of the dry mass of $I$. hederifolia and I. quamoclit, respectively, indicating that high spray volume provide higher efficacy of saflufenacil to control morning-glory species and this augmenting provides a better control of $I$. quamoclit in the same way that I. quamoclit is better controlled than I. hederifolia using this herbicide.

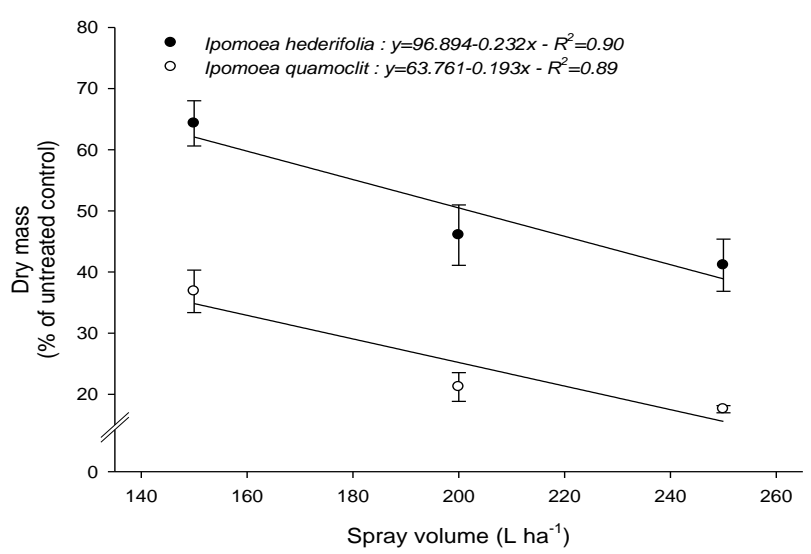

Figure 2. Relation between the percentage of dry mass of Ipomoea hederifolia and Ipomoea quamoclit, compared to a herbicide-free check, and the spray volume

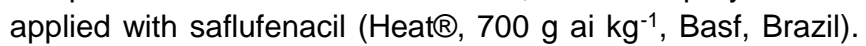
Vertical lines indicate the standard error of the mean of four replicates.

Spray temperature. The ANOVA was significant $(P<0.05)$ to plant species, indicating that $I$. hederifolia and $I$. quamoclit responded differently to carfentrazone-ethyl spraying when spray temperature increased, so that two equations were required to provide the relation between the increasing of spray temperature and the effect on the decreasing of dry mass of both species (Figure 3). According to the equation, increasing $1{ }^{\circ} \mathrm{C}$ in spray temperature reduces $0.22 \%$ and $0.35 \%$ of the dry mass of $I$. hederifolia and I. quamoclit, respectively, indicating that high spray temperature provide higher efficacy of saflufenacil to control morning-glory species and this augmenting provide a better control of $l$. hederifolia than I. quamoclit in spite of $I$. hederifolia is better controlled than I. quamoclit using this herbicide.

The ANOVA was significant $(P<0.05)$ to plant species, indicating that $I$. hederifolia and $I$. quamoclit responded differently to saflufenacil spraying when spray temperature increased, so that two equations were required to provide the relation between the increasing of spray temperature and the effect on the decreasing of dry mass of both species (Figure 4). According to the equation, increasing $1{ }^{\circ} \mathrm{C}$ in spray temperature reduces $0.56 \%$ and $0.30 \%$ of the dry mass of $I$. hederifolia and $I$. quamoclit, respectively, indicating that high spray temperature provide higher efficacy of saflufenacil to control morning-glory species and this augmenting provides a better control of I. hederofilia than I. quamoclit in the same way that I. hederifolia is better controlled than I. quamoclit using this herbicide.

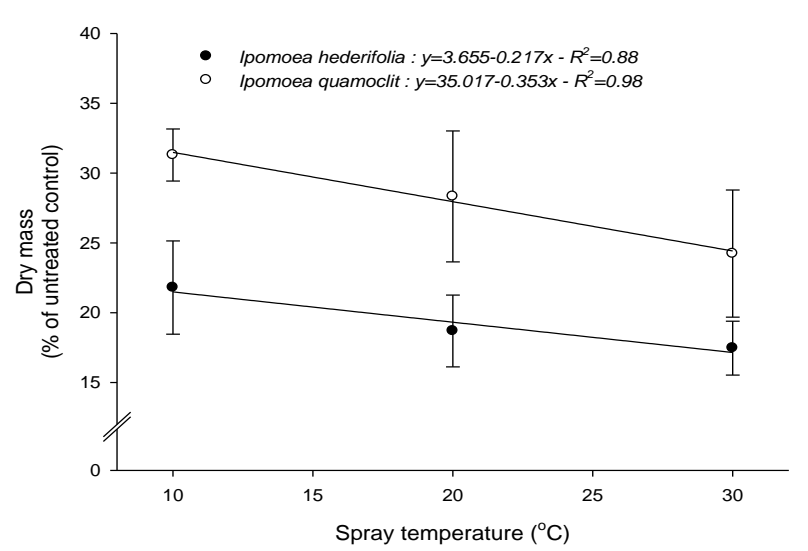

Figure 3. Relation between the percentage of dry mass of Ipomoea hederifolia and Ipomoea quamoclit, compared to a herbicide-free check, and the spray temperature applied with carfentrazone-ethyl (Aurora $\AA$, $400 \mathrm{~g}$ ai L $\mathrm{L}^{-1}$, FMC, Brazil). Vertical lines indicate the standard error of the mean of four replicates.

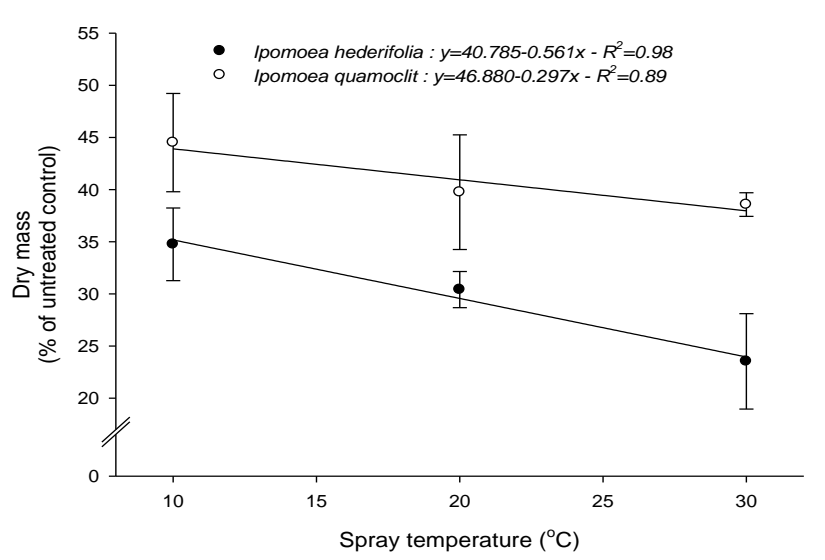

Figure 4. Relation between the percentage of dry mass of Ipomoea hederifolia and Ipomoea quamoclit, compared to a herbicide-free check, and the spray temperature applied with saflufenacil (Heat ${ }^{\circledR}, 700 \mathrm{~g}$ ai kg-1 ${ }^{-1}$, Basf, Brazil). Vertical lines indicate the standard error of the mean of four replicates.

\section{DISCUSSION}

By using non-lethal doses of carfentrazone-ethyl and saflufenacil, we observed that the increase of both 
spray volume and spray temperature provide a better control of $I$. hederifolia and I. quamoclit. In spite of not being the objective of applying herbicides to control weeds, the use of non-lethal doses, in this research, did not interfere with the effect of the spray volume and the spray temperature due to be a threshold dose between the surviving of the plant death. If higher doses were used, plants could be rapid killed and the desired effect of treatments, probably, were masked.

Studies of Campos et al. (2011), testing two spray volumes (200 and $400 \mathrm{~L} \mathrm{ha}^{-1}$ ) and three herbicides (glyphosate, paraquat+diuron, and glufosinate), they concluded that there was the highest efficacy using spray volumes lower than $200 \mathrm{~L} \mathrm{ha}^{-1}$ and, in general, spray volumes higher than $400 \mathrm{~L}$ ha $^{-1}$ are not recommended as well as lower than 100-150 $\mathrm{L}$ ha-1. According to Galon et al. (2007), for contact herbicides, there is generally needed high spray volumes, as observed in this research, since herbicide efficacy is dependent on the covering of leaf surface; while systemic herbicides can be sprayed at plant shoot by using low spray volume.

Spray volume required to an efficient postemergence control, according to King and Oliver (1992), is dependent on the target weeds, or even the plant age/stage, the herbicide, and the environmental conditions at the time of spraying. Under some situations, the use of adequate management and under specific environmental conditions, reduced spray volumes can be used with an efficient control of weeds (Devlin et al. 1991). However, changes on physicchemical properties of herbicides have to be considered, can causing negative effects on herbicide penetration and absorption (Willis 1984, Fawcett et al. 1987).

Spray temperature, as well as spray volume, can influence on physic-chemical properties of herbicides (as viscosity, $\mathrm{pH}$, electrical conductivity, and so on), in addition to solubilize epicuticular waxes, facilitating the penetration of some herbicides and, as a consequence, spray herbicide and efficacy of control are improved (Cunha et al. 2010). Downer et al. (1998) report the influence of spray temperature on physicchemical properties of herbicides affecting on herbicide efficacy due to the effect on the potential of spray drift. Therefore, in all those cases, an adequate use of both spray volume and spray temperature can improve the control of weeds.

\section{CONCLUSION}

The efficacy of carfentrazone-ethyl and saflufenacil to control $I$. hederifolia and $I$. quamoclit is dependent on both spray temperature and spray volume. The use of spray temperature next to $30{ }^{\circ} \mathrm{C}$ and spray volume next to $250 \mathrm{~L}$ ha-1 can provide a better control of those species.

\section{Funding}

This research was sponsored in part by FAPESC (TO 2013TR3293), SC, Brazil.

\section{References}

Agostineto MC, Ansolin HH, Carvalho LB. 2015. Dose-response of morning-glory species to PPO inhibitors. Commun Plant Sci 5: 23 27.

Carvalho LB, Bianco S, Pitelli RA. 2009. Growth and mineral nutrition of Ipomoea quamoclit. Planta Daninha 27: 283-288.

Carvalho LB, Bianco S, Bianco MS. 2014. Estudo comparativo do acúmulo de massa seca e macronutrientes por plantas de Zea mays e Ipomoea hederifolia. Planta Daninha 32: 99-107.

Campos CF, Martins D, Rodrigues ACP, Cardoso LA, Silva JIC, Costa NV. 2011. Efeito de diferentes herbicidas, doses e volume de calda na dessecação de milheto [Pennisetum glaucum (L. Leek)]. Arqu Inst Biol 78: 63-69.

Cunha JPAR, Alves GS, Reis EF. 2010. Efeito da temperatura nas características físico-químicas de soluções aquosas com adjuvantes de uso agrícola. Planta Daninha 28: 665-672.

Devlin DL, Long JH, Maddux LD. 1991. Using reduced rates of postemergence herbicides in soybeans (Glycine max). Weed Technol 5: 834-840.

Downer RA, Hall FR, Thompson RS, Chapple AC. 1998. Temperature effects on atomization by flat-fan nozzles: implications for drift management and evidence for surfactant concentration gradients. Atom Sprays 8: 241-254.

Fawcett JA, Harvey RG, Arnold WE, Bauman TT, Eberlein CV, Kells JJ, Moshier LJ, Slife FW, Wilson RG. 1987. Influence of environment on corn (Zea mays) tolerance to sethoxydim. Weed Sci 35: 568-575.

Ferreira RV, Contato ED, Kuva MA, Ferraudo AS, Alves PLCA, Magario FB, Salgado TP. 2011. Organização das comunidades infestantes de plantas daninhas na cultura da cana-de-açúcar em agrupamentos-padrão. Planta Daninha 29: 363-371.

Galon L, Oliveira Pinto JJ, Agostinetto D, Dal Magro T. 2007. Controle de plantas daninhas e seletividade de herbicidas à cultura da soja, aplicados em dois volumes de calda. Rev Bras Agrociênc 13: 325-330.

Giancotti PRF, Toledo REB, Alves PLCA, Victoria Filho R, Cason JB, Rocha MG. 2014. Chemical control of morning glory as a function of water restriction levels. Planta Daninha 32: 345-353.

King CA, Oliver LP. 1992. Application rate and timing of acifluorfen, bentazon, chlorimuron, and imazaquin. Weed Technol 6: 526-534.

Kuva MA, Pitelli RA, Salgado TP, Alves PLCA. 2007. Fitossociologia de comunidades de plantas daninhas em agroecossistema canacrua. Planta Daninha 25: 501-511.

MAPA - Ministério da Agricultura Pecuária e Abastecimento do Brasil. 2014a. Sistema de Agrotóxicos Fitossanitários. Carfentrazone-ethyl. Ministério da Agricultura Pecuária e Abastecimento, Brasil. <http://agrofit.agricultura.gov.br>.

MAPA - Ministério da Agricultura Pecuária e Abastecimento do Brasil. 2014b. Sistema de Agrotóxicos Fitossanitários. Saflufenacil. Ministério da Agricultura Pecuária e Abastecimento, Brasil. <http://agrofit.agricultura.gov.br>.

Nicolai M, Christoffoleti PJ. 2014. Tecnologia de aplicação de herbicidas. In: Monquero PA. Aspectos da biologia e manejo das plantas daninhas. RIMA: São Carlos. pp.307-350.

Wills GD. 1984. Toxicity and translocation of sethoxydim in bermudagrass (Cynodon dactylon (L.) Pers.) as affected by environment. Weed Sci 32:20-24. 


\section{RESUMO}

Temperatura e volume de calda influenciam na eficácia de carfentrazone-ethyl e saflufenacil para controle de corda-deviola. O objetivo desta pesquisa foi relacionar a resposta de Ipomoea hederifolia e Ipomoea quamoclit com a variação na temperatura da calda e no volume de calda de carfentrazone-ethyl and saflufenacil. Dois experimentos em vasos foram conduzidos para relacionar as temperaturas da calda $\left(10,20\right.$ e $\left.30^{\circ} \mathrm{C}\right)$ e os volumes de calda (150, 200 e $\left.250 \mathrm{~L} \mathrm{ha}^{-1}\right)$ com o acúmulo de massa seca das plantas após a aplicação de $2 \mathrm{~mL} \mathrm{ha}^{-1}$ e $0,5 \mathrm{~g} \mathrm{ha}^{-1}$ de herbicida comercial com carfentrazone-ethyl (Aurora®) e saflufenacil (Heat®). Quatorze dias após a aplicação, a massa seca da parte aérea foi determinada. Os dados foram expressos em relação à testemunha sem aplicação de herbicida e submetidos à análise de regressão linear. $O$ aumento de $10 \mathrm{~L} \mathrm{ha}^{-1}$ no volume de calda reduziu em $1,34 \%$ a massa seca de ambas as espécies, usando carfentrazone-ethyl, e $2,32 \%$ e $1,93 \%$ da massa seca de I. hederifolia e I. quamoclit, respectivamente, usando saflufencil. Além disso, o aumento de $1^{\circ} \mathrm{C}$ na temperatura da calda reduziu em $0,22 \%$ e $0,35 \%$ a massa seca de $I$. hederifolia e $I$. quamoclit, respectivamente, usando carfentrazone-ethyl, e $0,56 \%$ e $0,30 \%$ da massa seca dessas espécies, respectivamente, usando saflufencil. A eficácia de carfentrazone-ethyl e saflufenacil para o controle de I. hederifolia e 1 . quamoclit é dependente da temperatura da calda e do volume de calda. $O$ uso de temperatura da calda próxima a $30{ }^{\circ} \mathrm{C}$ e volume de calda próximo a $250 \mathrm{~L} \mathrm{ha}^{-1}$ pode acarretar em melhor controle se amdas as espécies.

Palavras-chave: Inibidores de PROTOX, herbicidas, características da calda. 